\title{
Mykoła DOROSZKO
}

Kijowski Uniwersytet Narodowy im. Tarasa Szewczenki

doroshko7@ukr.net

\section{DLACZEGO PUTIN WSZCZĄŁ WOJNĘ PRZECIW UKRAINIE?}

\section{ABSTRACT Why Putin Started War Against Ukraine?}

The author analyzes the causes and consequences of undeclared war of Russia against Ukraine. Among the main reasons - the desire to restore Russian leadership's geopolitical influence in the former Soviet Union by building a new type of empire. In order to reach it official Moscow uses a wide range of tools - from economic pressure and blackmail to armed aggression on the territories of the former USSR. The author is convinced that the annexation of the Crimea and the undeclared war of Russia against Ukraine were the result of revanchist policy of Russian President Vladimir Putin aimed at the return of influential world power status. Achieving this goal involves prevention of Europeanisation and democratization of post-Soviet countries, the main jewel among which is Ukraine. Exit from the influence of Russia is possible, according to the author, through the integration of Ukraine into the EU and NATO.

Słowa kluczowe: rewanżyzm, Rosja, Putin, imperium, projekty integracyjne, „wojna o gaz”, euromajdan, agresja wojskowa, wojna hybrydowa, sankcje

Keywords: revanchism, Russia, Putin, Empire, integration projects, "gas war", euromaidan, annexation, military aggression, hybrid war, sanctions

W W jego wypowiedzi, które są kluczowe dla zrekonstruowania jego politycznego credo. Pierwsze stwierdzenie dotyczy faktu, że upadek Związku Sowieckiego był największa katastrofa geopolityczna XX wieku, a drugie (które w istocie stanowi sedno 
owego credo) to konstatacja, że Rosja powinna być mocarstwem. Te wypowiedzi Putina w dużej mierze wyjaśniają przyczynę jego popularności w Rosji, ponieważ poglądy wyrażone przez prezydenta podziela bezwzględna większość jego współobywateli. Dla nich Putin, który z mało znanego w 1999 r. dyrektora rosyjskiej Federalnej Służby Bezpieczeństwa stał się faktycznym i wiecznym „włodarzem”, jest ucieleśnieniem nadziei na powrót utraconej wielkości.

W latach 90. okazało się, że Rosja, pozostając w postsowieckich granicach, nie jest w stanie odzyskać statusu mocarstwa. Putin już podczas swojej pierwszej kadencji prezydenckiej w latach 2000-2004 zdecydowanie wezwał przywódców kluczowych krajów byłego Związku Sowieckiego - Ukrainy, Białorusi i Kazachstanu, do zjednoczenia się i utworzenia pod egidą Rosji tak zwanej „wspólnej przestrzeni gospodarczej”. Ale na drodze do realizacji tego projektu „reanimacji Związku Sowieckiego” stanęła pomarańczowa rewolucja na Ukrainie w 2004 r., która uniemożliwiła dojście do władzy Putinowskiej marionetki - Wiktora Janukowycza.

Putin doskonale wiedział, że bez Ukrainy nowe imperium rosyjskie nie jest możliwe do zbudowania. Wszystkie jego wysiłki podczas drugiej kadencji prezydenckiej w latach 2004-2008 miały na celu zdyskredytowanie państwa ukraińskiego w oczach świata. Na początku użyto najnowszej kremlowskiej broni - „gazowej”. Korzystając ze statusu niemal monopolowego dostawcy gazu ziemnego do krajów Europy Środkowo-Wschodniej i Południowej, Rosja za pomocą tak zwanych „wojen gazowych” starała się przekonać Unię Europejską o niewiarygodności Ukrainy jako głównego pośrednika w tranzycie rosyjskiego „błękitnego paliwa”.

Niezbędnym warunkiem uzyskania statusu kraju kandydującego do członkostwa w NATO jest przystąpienie do Planu Działań na rzecz Członkostwa (MAP). Aby przeszkodzić przyłączeniu Ukrainy do Sojuszu Północnoatlantyckiego, Putin w kwietniu 2008 r. pojechał na szczyt NATO w Bukareszcie i nakłaniał przywódców kluczowych europejskich państw należących do NATO - Niemiec i Francji, aby nie przyznawać MAP Ukrainie i Gruzji - państwom, które starają się wyjść z rosyjskiej strefy wpływów. Rosyjski przywódca przekonywał swoich kolegów z Niemiec, Francji, Włoch i Grecji (dwa ostatnie państwa także odmówiły Ukrainie przyznania Planu Działań na Rzecz Członkostwa), jak zwykle, za pomocą fałszywych argumentów „historycznych”. Twierdził, że nie można przyznać MAP Ukrainie w związku z tym, że Ukraina wogóle jest bardzo trudnym krajem. Ukraina w postaci, w jakiej dziś istnieje [...] powstata w czasach sowieckich; otrzymata terytorium od Polski - po II wojnie światowej, od Czechostowacji, od Rumunii - i nadal nie rozwiazata wszystkich problemów granicznych z Rumunia w rejonie Morza Czarnego [...]. Od Rosji otrzymata ogromne terytoria na wschodzie i potudniu. Jest to ztożona formacja państwowa. A jeśli jeszcze dotożyć tu problemy NATO [...] to w ogóle może to stawiać istnienie państwowości pod znakiem zapytania. [...] Nie mamy prawa weta, i nie możemy go mieć, nie pretendujemy nawet, ale chcę, żebyśmy wszyscy, kiedy podejmujemy podobnego rodzaju decyzje, rozumieli, $\dot{z}$ e my też mamy tam swoje interesy. [...] Na Ukrainie żyje siedemnaście milionów Rosjan [...]. Cate potudnie Ukrainy - tam sa tylko Rosjanie. Krym Ukraina otrzymata na mocy decyzji Biura Politycznego Komitetu Centralnego Komunistycznej Partii Zwiąku 
Radzieckiego. Nawet nie przeprowadzono procedur panstwowych zwiazanych z przeniesieniem terytorium ${ }^{1}$.

Ten obszerny cytat z przemówienia Putina w Bukareszcie w 2008 r. został przytoczony po to, aby czytelnik zrozumiał: przywódca Rosji, na długo przed aneksją Krymu i agresją na wschodniej Ukrainie, de facto wyłożył zachodnim politykom argumenty, które wyjaśniają przyczyny obecnych działań rosyjskich na Ukrainie. Po pierwsze, to obecność na tych terenach dużej mniejszości rosyjskiej. Co prawda nie jest to $17 \mathrm{mln}$ osób, jak twierdzi Putin, a 8,334 mln lub 17,3\% populacji, według spisu ludności z 2001 r. ${ }^{2}$ Tych ludzi, czyli etnicznych Rosjan i tak zwanych „rosyjskojęzycznych”, Rosja Putina, jak pokazuje praktyka polityczna ostatnich lat, zamierza bronić wszelkimi sposobami, w tym także zbrojnymi, co potwierdziło się w sierpniu 2008 r. podczas pięciu dni wojny rosyjsko-gruzińskiej w Osetii Południowej, a teraz trwa we wschodniej Ukrainie.

Po drugie, Putin podał w wątpliwość integralność terytorialną Ukrainy, przedstawił swoje roszczenia co do Półwyspu Krymskiego, który - jak wiadomo - został przekazany przez Rosyjską Federacyjną Socjalistyczną Republikę Sowiecką - Ukraińskiej Socjalistycznej Republice Sowieckiej w ramach ówczesnej procedury konstytucyjnej. Działo się to na mocy Ukazu Prezydium Rady Najwyższej ZSRS i odpowiedniej Ustawy ZSRS o przekazaniu regionu krymskiego z RSFSR do ukraińskiej SRS 3 .

Po trzecie trzeba dodać, że odmowa krajów członkowskich NATO przyznania MAP Ukrainie i Gruzji oznaczała, iż Rosja, która nie jest członkiem NATO, ma faktyczne prawo weta co do decyzji suwerennych państw - członków Sojuszu. Sfałszowane przez Putina argumenty wpłynęly na wyniki głosowania czterech przywódców europejskich państw członkowskich NATO, przeważając w ten sposób stanowisko prezydenta USA George’a W. Busha, który był aktywnym zwolennikiem zaproponowania Ukrainie i Gruzji Planu Działań na rzecz Członkostwa.

Po zwycięstwie w Bukareszcie Putin, który wiosną 2008 r. tymczasowo przesiadł się z fotela prezydenckiego na fotel premiera, sprowokował w sierpniu tego roku konflikt zbrojny w kontrolowanej przez Kreml Osetii Południowej - separatystycznej enklawie w Gruzji. Tym samym rosyjski przywódca dał sygnał światu, że Rosja jest gotowa do użycia siły, gdy chodzi o obronę przed wpływami Zachodu terytoriów, które pozostają w jej strefie wpływów.

Potem przyszły wybory prezydenckie w 2010 r. na Ukrainie i rewanż Putina oraz jego protegowanego Janukowycza, który natychmiast przekreślił euroatlantycki kurs Ukrainy tzw. „umowami charkowskimi”, a także niemal wieczystym przedłużeniem stacjonowania Floty Czarnomorskiej na terytorium ukraińskiego Krymu i ustawo-

Por.: Выступцение ВАадимира Путина на саммите НАTO, Бухарест, 4 IV 2008, [online] http:// www.unian.net/politics/110868-vyistuplenie-vladimira-putina-na-sammite-nato-buharest-4-aprelya-2008-goda.html, 15 V 2015.

2 Dane dotyczące liczby i składu etnicznego ludności na podstawie Narodowego Spisu Powszechnego z 2001 r., [online] http://2001.ukrcensus.gov.ua/rus/results/general/nationality, 15 V 2015.

3 Por.: В. Головченко, В. Матвієнко, Аипломатична історія України (1923-1993 роки). Навчальний посібник, Киев 2012, s. 177-178. 
dawczym wzmocnieniem neutralnego statusu Ukrainy. Kolejne etapy demontażu państwa ukraińskiego pod kontrolą kremlowskiej marionetki - Janukowycza, następowały z takim powodzeniem, że rosyjski sternik był przekonany o jak najrychlejszym wejściu Ukrainy do Euroazjatyckiej Unii Gospodarczej (taką nazwę nosi rosyjski projekt integracyjny - wersja „prototypowa” nowego Imperium Rosyjskiego); mówiono nawet o dacie przystąpienia - 1 stycznia $2015 \mathrm{r}$.

Wszystko świadczyło o udanej realizacji przez Janukowycza Putinowskiego planu zniszczenia Ukrainy, jej gospodarki, armii, służb mundurowych etc. Głównymi osiągnięciami Putina na szlaku przekształcenia Ukrainy w dodatek do Rosji były: odmowa podpisania przez Janukowycza umowy o stowarzyszeniu Ukrainy z UE w Wilnie, znaczne zniżki na gaz ziemny eksportowany z Rosji na Ukrainę i pożyczka w wysokości 15 mld dolarów, udzielona przez Moskwę rządowi Janukowycza. Jednakże, podobnie jak w 2004 r., tak i pod koniec listopada roku 2013 w Kijowie zebrał się Majdan, tym razem pod nazwą Euromajdan. Naród ukraiński po raz kolejny przypomniał Putinowi i jego „piątej kolumnie”, że Ukraina jest państwem europejskim i jej miejsce jest w Unii Europejskiej, a nie Euroazjatyckiej.

Następnie doszło do ucieczki Janukowycza i - co za tym idzie - zmiany władzy na Ukrainie, a mściwy KGB-ista Putin wykorzystał ten proces do aneksji ukraińskiego Krymu i rozpoczęcia działań zbrojnych na wschodzie Ukrainy. Dlaczego Rosja uciekła się do siłowych rozwiązań, łamiąc prawo międzynarodowe? Jaki cel przyświeca Putinowi prowadzącemu wojnę na Ukrainie?

Główne cele agresywnej polityki Putina na Ukrainie to: przywrócenie na tym terenie rosyjskich wpływów; utwierdzenie w świadomości Rosjan mitu o Putinie jako jednoczycielu „rosyjskich terytoriów historycznych”; podzielenie Unii Europejskiej przez obalenie przeświadczenia o jej udanym projekcie integracyjnym. Dla realizacji tego potrójnego zadania Kreml posunął się do zastosowania wojny hybrydowej na Ukrainie w celu destabilizacji sytuacji w tym kraju w sferze politycznej, gospodarczej i informacyjnej.

Wojna hybrydowa, jak wiadomo, przewiduje szereg odpowiednich środków - od destabilizacji sytuacji w kraju (regionie) do jego pełnej okupacji. Pierwszym krokiem w kierunku destabilizacji sytuacji na Krymie i w Donbasie było przeprowadzenie przez rosyjskie służby bezpieczeństwa udanej operacji dywersyjnej, w wyniku której agresorom udało się w tych regionach przeciągnąć na swoją stronę tak zwaną ludność rosyjskojęzyczną, aby wykorzystać ją jako „piątą kolumnę" w mającym nastąpić zajęciu terytorium Ukrainy.

Obecnie, jak zaznacza ukraiński badacz konfliktów Grigoryj Perepełycia, wojna hybrydowa Rosji na Ukrainie jest prowadzona w formie dziatań dywersyjno-rozpoznawczych, a takize systematycznych dziatań bojowych z udziatem wojsk rosyjskich, sit specjalnych, bojowników i lokalnych separatystów, którzy są teraz częścia Sit Zbrojnych Federacji Rosyjskiej.

I. Капсамун, Час вимагає визначеності, Аень, 14 I 2015, [online] http://www.day.kiev.ua/uk/ article/tema-dnya-podrobyci/chas-vymagaye-vyznachenosti, 15 V 2015. 
Po rozpoczęciu działań wojskowych we wschodniej Ukrainie Rosja wiosną 2014 r., przy pomocy uzbrojonych separatystów z tak zwanej Donieckiej Republiki Ludowej i Ługańskiej Republiki Ludowej, wyłączyła spod kontroli Kijowa około jednej trzeciej terytorium regionów donieckiego i ługańskiego. Wszystko po to, aby utworzyć na okupowanych ukraińskich terytoriach przyczółek dla dalszej ofensywy na wschodzie i południu Ukrainy. Prezydent Rosji Władimir Putin, jak oświadczyła stała przedstawicielka USA przy ONZ Samantha Power, na posiedzeniu Rady Bezpieczeństwa 21 stycznia 2015 r. zaproponował swojemu ukraińskiemu odpowiednikowi - Petrowi Poroszence, identyczny scenariusz rozwiązania konfliktu w Donbasie, jaki Rosja zastosowała swego czasu w Abchazji - prokremlowskiej separatystycznej enklawie w Gruzji. Zaproponowany przez Putina „abchaski scenariusz” zakłada, według amerykańskiej ambasador, legitymizacjęprzejęcia terytorium przez separatystów po podpisaniu porozumień z Mińska z 5 i 19 września 2014 r. oraz obecność rosyjskiego personelu i sprzętu wojskowego na terytorium Ukrainy. Gdy prezydent Poroszenko odrzucił rosyjską propozycję, Kreml oskarżył Kijów o niechęć do zaprowadzenia pokoju na wschodzie krajus.

Nie legitymizując swojej obecności na Ukrainie, Kreml po raz kolejny w ciągu ostatniego roku doprowadził do eskalacji konfliktu wojskowego. W połowie stycznia $2015 \mathrm{r}$. próbował w ten sposób zmusić Kijów do negocjacji na fali porażek wojskowych armii ukraińskiej, jak to miało miejsce we wrześniu roku ubiegłego. Putin, który otrzymał dwa międzynarodowe „policzki” na przełomie lat 2014 i 2015 - pierwszy to odwołanie, de facto z inicjatywy Niemiec, szczytu przywódców czwórki normandzkiej (Ukraina, Rosja, Niemcy i Francja) w Astanie, a drugi to odmowa Polski zaproszenia Putina na obchody 70. rocznicy wyzwolenia obozu w Auschwitz przez sojuszników z koalicji antyhitlerowskiej - oczekiwał nowych ustępstw ze strony Ukrainy na kolejnych negocjacjach przywódców krajów czwórki normandzkiej w Mińsku 12 lutego, co oznacza, że zamierza w dalszym ciągu wywierać presję na Ukrainę. W tym celu jest gotowy do dalszego używania argumentów militarnych, gospodarczych, humanitarnych etc., które są częścią prowadzonej na Ukrainie wojny hybrydowej.

Hybrydowa wojna Rosji przeciwko Ukrainie ma charakter globalny: w Donbasie przejawia się w formie walk zbrojnych, a na arenie międzynarodowej jest prowadzona środkami informacyjnymi - i na razie Ukraina ją przegrywa. Ukształtowało się na świecie trwałe przekonanie, że Rosja rzeczywiście nie ma nic wspólnego z konfliktem w Donbasie, choć może pomagać separatystom. Do utrwalenia takiej wizji przyczynia się także przekonanie, że skoro Ukraina nie ogłosiła stanu wojennego, oznacza to, że nie prowadzi wojny z Rosją. Daje to Rosji możliwość uniknięcia odpowiedzialności i przerzucenia jej na tych, których ukraiński rząd nazywa „terrorystami”. Dlatego to my - Ukraińcy musimy kształtować międzynarodową opinię, że to właśnie Rosja jest agresorem, a nie terrorystyczne: Doniecka Republika Ludowa i Ługańska Republika Ludowa ${ }^{6}$.

Путин предлагал Порошенко легитимизачию захватов боевиков, Хартыя'97, 22 I 2015, [online] http://www.charter97.org/ru/news/2015/1/22/136356, 15 V 2015.

6 Por.: Г. Перепелиця, Час вимагає визначеності, Аень, 14 I 2015, [online] http://www.day.kiev.ua/ uk/article/tema-dnya-podrobyci/chas-vymagaye-vyznachenosti, 15 V 2015. 
Zachód, który stopniowo uświadamia sobie niebezpieczeństwo nowej wojny w Europie, na wieść o tym, że regularne oddziały wojska rosyjskiego walczą w Donbasie, a jednocześnie rozszerza się rosyjska obecność wojskowa na Krymie, powinien zapewnić Ukrainie nie tylko wojskową, ale również finansową pomoc. Celem presji ekonomicznej wywieranej przez Rosję jest bowiem krach gospodarki ukraińskiej, który według oczekiwań Putina ma nastąpić w 2015 r. W ten sposób stara się on udowodnić Zachodowi niewydolność zachodniego modelu gospodarczego w krajach postkomunistycznych i pokazać niegotowość USA, UE i międzynarodowych instytucji finansowych do podjęcia ciężaru opieki nad gospodarką Ukrainy, która praktycznie jest w stanie bankructwa. Jeżeli rzeczywiste wydarzenia potoczyłyby się według scenariusza Putina, to jedynym zbawicielem ukraińskiej gospodarki miałaby być Rosja, która zawraca Ukrainę na drogę integracji z Eroazjatycką Unią Celną i Euroazjatycką Unią Gospodarczą, uniemożliwiając jednocześnie realizację umowy stowarzyszeniowej Ukrainy z UE i pozbawiając ją tym samym wszelkich perspektyw integracji z Unią Europejską.

Jednak nie wszystko zależy teraz od Putina. Jak zauważył prezydent USA Barack Obama w swoim dorocznym przemówieniu do narodu amerykańskiego 20 stycznia 2015 r., sytuacja z lata roku 2014, gdy niektórzy wierzyli, że agresja Putina byta mistrzowskim pokazem strategii i sity, zmieniła się zasadniczo. Dzisiaj - stwierdził prezydent USA - wtaśnie Ameryka jest silna i zjednoczona ze swoimi sojusznikami, podczas gdy Rosja - jest izolowana, a jej gospodarka jest w ruinie?.

Dzisiaj, jak zauważył były ambasador USA na Ukrainie Steven Pifer, Putin zrozumiał, że jego działania drogo go kosztują. Stany Zjednoczone i Europa obrały wspólny kurs, stosując coraz surowsze sankcje. Środki te, w połączeniu ze spadkiem cen ropy naftowej, dały o sobie znać w Rosji: odpływ kapitału wyniósł 150 mld dolarów w 2014 r., rubel stracił połowę swojej wartości w porównaniu do ubiegłego roku. Urzędnicy w Moskwie oczekują, że spadek gospodarczy wyniesie prawie 5\% w roku 2015, a rosyjskie firmy próbują zgadnąć, w jaki sposób będą refinansować kredyty na dziesiątki miliardów dolarów, których termin płatności przypada w tym roku

Dlatego zachodni przywódcy powinni pracować nad tym, aby utrzymać i wzmacniać reakcję Zachodu na rosyjską agresję na Ukrainie. USA, UE i międzynarodowe instytucje finansowe winny przygotować pakiet dodatkowej pomocy finansowej dla Ukrainy, podczas gdy Kijów realizuje ważne reformy gospodarcze. USA i inne państwa członkowskie NATO powinny jak najszybciej zapewnić zwiększoną pomoc wojskową Ukrainie, aby lepiej bronić siebie i zapobiec dalszej eskalacji agresji ze strony Rosji. Jeśli Zachód pomoże Ukraińcom powstrzymać rosyjski scenariusz militarny, a sankcje nadal będą oddziaływać na gospodarkę rosyjską, jest szansa, że Kreml zechce zmienić kurs i dążyć do osiągnięcia prawdziwego porozumienia politycznego.

Por.: M. Sirczuk, Підтримка України, протистояння Росії. Послання Обами американській нації, Аень, 28 I 2015, [online] http://www.day.kiev.ua/uk/article/den-planety/pidtrymka-ukrayiny-protystoyannya-rosiyi, $15 \mathrm{~V} 2015$.

Tamże. 
Kiedy to nastąpi - nie wiadomo. Wszystkie poprzednie kroki Putina utwierdzają nas w tym, że rosyjski „car” nie zadowoli się aneksją Krymu i okupacją części Donbasu. Powstrzymać Putina może tylko stworzenie skutecznej antyputinowskiej koalicji, na kształt antyhitlerowskiej z lat 1942-1945.

\section{BIBLIOGRAFIA}

Sirczuk М., Підтримка України, протистояння Росії. Послання Обами американській нащіï, Аень, 28 I 2015, [online] http://www.day.kiev.ua/uk/article/den-planety/pidtrymka-ukrayiny-protystoyannya-rosiyi.

Выступление ВАадимира Путина на саммите НАТО, Бухарест, 4 IV 2008, [online] http://www.unian.net/politics/110868-vyistuplenie-vladimira-putina-na-sammite-nato-buharest-4-aprelya-2008-goda.html.

Головченко В., Матвієнко В.,Аилломатична історія України (1923-1993роки). Навчальний посібник, Киев 2012.

Капсамун I., Час вимагає визначеності, Аень, 14 I 2015, [online] http://www.day.kiev.ua/uk/ article/tema-dnya-podrobyci/chas-vymagaye-vyznachenosti.

Путин предлагал Пороменко легитимизаиию захватов боевиков, Хартыя'97, 22 I 2015, [online] http://www.charter97.org/ru/news/2015/1/22/136356.

Перепелиця Г., Час вимагає визначеності, Аень, 14 I 2015, [online] http://www.day.kiev.ua/ uk/article/tema-dnya-podrobyci/chas-vymagaye-vyznachenosti.

Ttumaczenie Magdalena Romanowska

Prof. Mykoła DOROSZKO - wicedyrektor Instytutu Stosunków Międzynarodowych Kijowskiego Uniwersytetu Narodowego im. Tarasa Szewczenki. 